\title{
Tubulocystic renal cell carcinoma: Report of a rare case
}

\author{
Aanchal Kakkar, MD; Mehar C. Sharma, MD, FRCPath; ${ }^{*}$ Manpreet Uppal, MBBS,; Sunil Chumber, MS ${ }^{\varsigma}$
}

*Department of Pathology, All India Institute of Medical Sciences, New Delhi, India; §Department of Surgical Disciplines, All India Institute of Medical Sciences, New Delhi, India

Cite as: Can Urol Assoc J 2015; (9-10):E654-7. http://dx.doi.org/10.5489/cuaj.2935 Published online September 9, 2015.

\section{Abstract}

Cystic neoplasms of the kidney are rare, and present a unique diagnostic challenge. We report the case of an elderly male who presented with a large cystic neoplasm, which was a diagnostic dilemma clinically and radiologically. Histopathological examination showed a tumour composed of variably sized tubules lined by atypical cells having large round nuclei with prominent nucleoli. Hobnailing was seen at places. Tumour cells were immunopositive for pancytokeratin, vimentin, CD10, CK19 and AMACR, confirming a diagnosis of tubulocystic renal cell carcinoma (TC-RCC).

\section{Introduction}

Cystic neoplasms of the kidney are rare, accounting for about $10 \%$ of renal cell carcinomas (RCC). They present a unique diagnostic challenge as they include diverse differential diagnoses, radiological features are not always conclusive, and they include some newer unknown entities. We report the case of an elderly male with a large cystic neoplasm in the kidney, which presented a diagnostic dilemma clinically and radiologically.

\section{Case report}

This 65-year-old male presented with complaints of left flank pain for 6 months. The pain was dull, aching, and did not radiate to any other site. He had also noticed a mass in the left flank, which gradually increased in size. There was history of intermittent fever, as well as significant weight loss and loss of appetite. History of dysuria or hematuria was absent. On examination, a $12 \times 16-\mathrm{cm}$ mass was identified in the left lumbar and iliac regions. The mass was non-tender, firm in consistency, had well-defined borders, lobulated surface, and moved minimally with respiration.
Abdominal ultrasound showed a complicated cystic lesion with internal septations, debris, and hemorrhage. Contrastenhanced computerized tomography of the abdomen revealed a large, solid-cystic lesion with enhancing septae arising from lateral margin of the left kidney. Radiologically, it was considered a Bosniak grade IV lesion, with possibilities of RCC with cystic change, some other cystic neoplasm or a hydatid cyst. Hydatid serology was negative, and the patient underwent a left radical nephrectomy with a clinical diagnosis of a malignant cystic neoplasm. Intraoperatively, a lobulated cystic mass was seen replacing the whole left kidney. In total, $70 \mathrm{~mL}$ of brownish fluid was aspirated from the cystic areas.

\section{Pathological examination}

On gross examination, a left nephrectomy specimen measured $16 \times 14 \times 9 \mathrm{~cm}$ and weighed 600 grams. A large brown, fleshy tumour measuring $15 \times 12 \times 5 \mathrm{~cm}$, with numerous large and small cysts within it, was identified (Fig. 1). The overlying renal capsule was intact. The tumour reached the renal pelvis.

Microscopic examination (Fig. 2) showed a tumour composed of well-formed small-sized to medium-sized tubules and cystically dilated larger tubules, separated by thin fibrovascular septae. These luminal spaces were lined by atypical cuboidal to columnar cells with abundant eosinophilic cytoplasm. Nuclei were large, round, vesicular, with prominent nucleoli (nucleolar grade 3). At places, the tumour cells showed hobnailing. Mitoses were infrequent. The fibrous septae separating the tubules were pauci-cellular and lacked the appearance of ovarian stroma. No solid sheets of cells, groups of neoplastic clear cells or papillary structures were identified. Based on the histomorphological features, a diagnosis of tubulocystic RCC (TC-RCC) was considered.

An immunohistochemical panel was applied to confirm the diagnosis and rule out tumours with similar morphology, such as collecting duct carcinoma and mixed epithelial stromal tumour (MEST). Tumour cells demonstrated immu- 


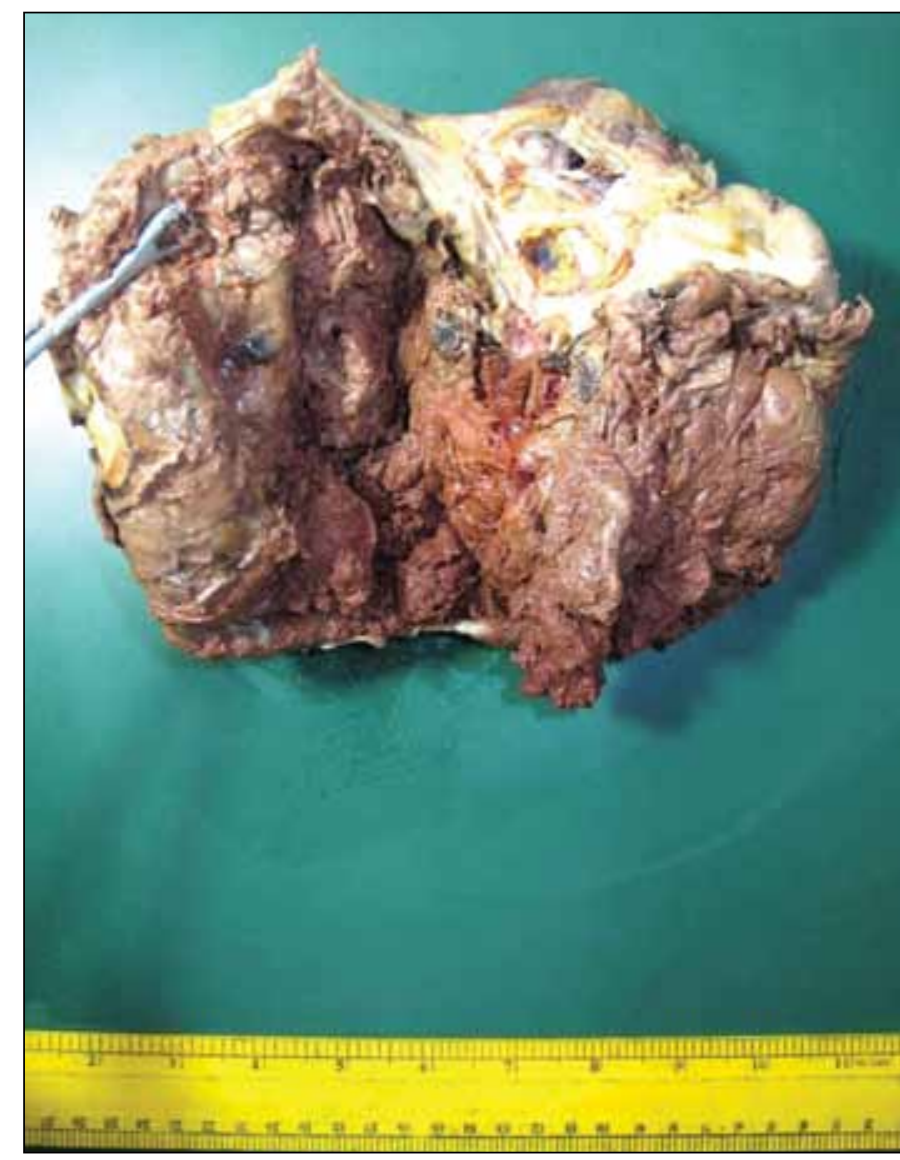

Fig. 1. Left nephrectomy specimen shows a large brown, fleshy tumour with numerous variably sized cysts. nopositivity for pancytokeratin, vimentin, CD10, CK19 and AMACR (Fig. 3), and were negative for CK7. No reactivity for estrogen receptors, progesterone receptors or smooth muscle actin was noted in the stroma. A final diagnosis of TC-RCC was rendered. At last follow-up, the patient had no evidence of disease recurrence or progression 1 year after surgery.

\section{Discussion}

TC-RCC is a rare, relatively new entity, previously described as "Bellinian epithelioma" and "low-grade collecting-duct carcinoma." ${ }^{11}$ It has recently been included in the International Society of Urological Pathology (ISUP) Vancouver Classification of Renal Neoplasia as a new renal epithelial tumour. About 70 cases have been reported to date. $^{1}$

TC-RCC is a tumour of adulthood, with a mean age of 60 years and a strong male preponderance. ${ }^{1-3}$ Patients are often asymptomatic, which has been attributed to the small size of these tumours (usually $<2 \mathrm{~cm}$ ). Patients harbouring larger tumours may, however, present with abdominal pain, distension, or even hematuria. ${ }^{4}$ These tumours are circumscribed, unencapsulated, and cortical in location. Their cut surface has been described as having a spongy, "bubble-wrap" or "Swiss cheese" appearance, imparted by the numerous variably sized cysts.

On microscopy, these dilated tubules and cysts are lined by a single layer of neoplastic cells which range from flat, hobnail, cuboidal, cylindrical to columnar. They are sepa-
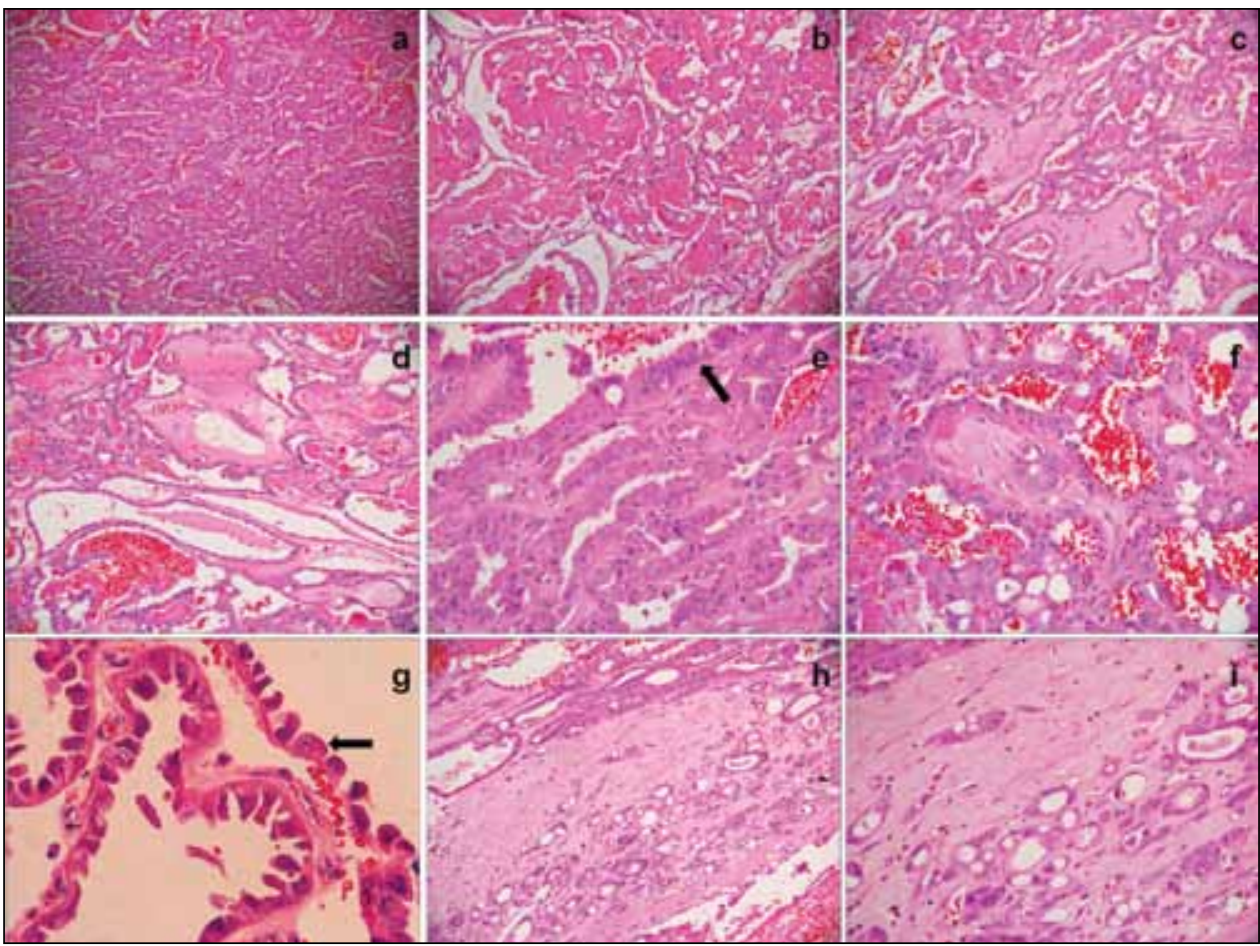

Fig. 2. Photomicrographs show a tumour composed of variably sized tubules (a: Hematoxylin and eosin stain [H\&E] $\times 100)$ and cystic spaces $(b: H \& E \times 100)$ that are separated by thin, hypocellular fibrovascular septae (c: $H \& E \times 200)$, with the lining epithelium showing tombstone appearance focally (d: $H \& E \times 200$ ); the tubules are lined by atypical cuboidal to pseudostratified ciliated columnar cells (arrow) with abundant eosinophilic cytoplasm (e: $H \& E \times 400$ ), large round to ovoid nuclei with prominent nucleoli (f: $\mathrm{H} \& \mathrm{E} \times 400$ ) and hobnail appearance (g: $H \& E \times 600)$; solid areas show smaller tubules lined by similar atypical cells in a sclerotic stroma (h: H\&E $\times 200$; i: $H \& E \times 400$ ). 


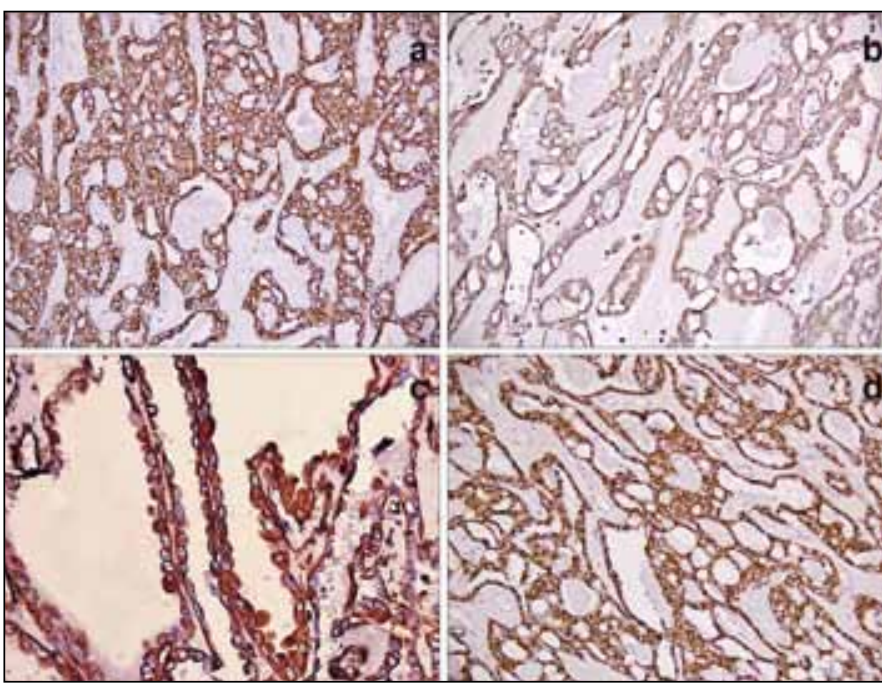

Fig. 3. Tumour cells are immunopositive for CK19 $(\mathrm{a}: \times 200)$, vimentin (b: $\times 200)$, CD10 (c: $\times 400)$ and AMACR (d: $\times 200)$.

rated by thin, hypocellular fibrous septa that lack ovariantype stroma or desmoplasia, as seen in MEST and CDC, respectively, or the myxoid, edematous stroma seen in oncocytoma with predominant tubulocystic pattern. ${ }^{5}$ Solid areas, small foci of clear cell change or papillary configuration are rare, and may herald aggressive behaviour and worsen clinical outcome. ${ }^{2,6,7}$ However, more recent data have suggested that TC-RCCs with focal dedifferentiation (TC-D-RCC) may actually represent hereditary leiomyomatosis RCC syndrome - associated RCC (HLRCC), as some TC-D-RCC cases show loss of fumarate hydratase immunoexpression and S-(2-Succino)-Cysteine (2SC) immunopositivity, similar to HLRCC (Table 1). ${ }^{8}$

The histogenesis of TC-RCC remains unclear. Tumour cells have some features of proximal nephron differentiation, and others related to distal nephron. Immunohistochemically, they are also positive for markers of proximal convoluted tubule (PCT) (CD10, carbonic anhydrase IX, vimentin, AMACR) as well as distal tubule/collecting duct (CK7, CK19, parvalbumin, BerEp4). ${ }^{9}$ Ultrastructurally, they display cells with abundant microvilli, with a brush border appearance resembling PCT, along with cells with complex cytoplasmic interdigitations reminiscent of intercalated cells of collect-

Table 1. Differential diagnoses of tubulocystic RCC

\begin{tabular}{|c|c|c|c|c|c|c|c|c|c|c|c|}
\hline \multirow[b]{2}{*}{ Diagnosis } & \multirow[b]{2}{*}{$\begin{array}{c}\text { Sex } \\
\text { predilection }\end{array}$} & \multirow[b]{2}{*}{$\begin{array}{c}\text { Gross } \\
\text { appearance }\end{array}$} & \multirow[b]{2}{*}{$\begin{array}{l}\text { Microscopy } \\
\text { on low } \\
\text { magnification }\end{array}$} & \multirow[b]{2}{*}{$\begin{array}{l}\text { Epithelial } \\
\text { features }\end{array}$} & \multirow[b]{2}{*}{$\begin{array}{l}\text { Nuclear } \\
\text { features }\end{array}$} & \multicolumn{6}{|c|}{ Immunohistochemistry } \\
\hline & & & & & & CD10 & CK7 & AMACR & $\begin{array}{l}\text { PAX8/ } \\
\text { PAX2 }\end{array}$ & $\begin{array}{c}\text { ER, PR } \\
\text { (stroma) }\end{array}$ & $\begin{array}{c}\text { Desmin/ } \\
\text { SMA } \\
\text { (stroma) }\end{array}$ \\
\hline TC-RCC & Males & $\begin{array}{c}\text { Cortical, } \\
\text { circumscribed, } \\
\text { bubble wrap } \\
\text { appearance }\end{array}$ & $\begin{array}{l}\text { Variably } \\
\text { sized cysts/ } \\
\text { tubules; thin, } \\
\text { hypocellular } \\
\text { septae }\end{array}$ & $\begin{array}{l}\text { Cuboidal, } \\
\text { hobnailing }\end{array}$ & $\begin{array}{c}\text { High } \\
\text { grade, } \\
\text { nucleoli }\end{array}$ & Pos & Neg & Pos & $\begin{array}{l}\text { Pos in } \\
<50 \%\end{array}$ & Neg & Neg \\
\hline $\mathrm{CN}$ & Females & Large cysts & $\begin{array}{c}\text { Variably } \\
\text { cellular, } \\
\text { ovarian-type } \\
\text { stroma }\end{array}$ & $\begin{array}{l}\text { Flat, low } \\
\text { cuboidal, } \\
\text { hobnailing }\end{array}$ & $\begin{array}{l}\text { Low } \\
\text { grade }\end{array}$ & Neg & Neg & Neg & Pos & Pos & Neg \\
\hline CDC & None & $\begin{array}{l}\text { Medullary/ } \\
\text { hilar, } \\
\text { infiltrative } \\
\text { mass }\end{array}$ & $\begin{array}{l}\text { Irregular, } \\
\text { angulated } \\
\text { glands } \\
\text { infiltrating } \\
\text { desmoplastic } \\
\text { stroma }\end{array}$ & $\begin{array}{c}\text { Marked } \\
\text { pleomorphism; } \\
\text { hobnailing }\end{array}$ & $\begin{array}{l}\text { High } \\
\text { nuclear } \\
\text { grade }\end{array}$ & Neg & Pos & Neg & Pos & Neg & Neg \\
\hline MC-RCC & None & $\begin{array}{l}\text { Variably sized } \\
\text { cysts }\end{array}$ & $\begin{array}{l}\text { Septae with } \\
\text { groups of } \\
\text { clear cells }\end{array}$ & $\begin{array}{l}\text { Cells with clear } \\
\text { cytoplasm }\end{array}$ & $\begin{array}{l}\text { Low } \\
\text { grade }\end{array}$ & Pos & Variable & Neg & Pos & Neg & Neg \\
\hline $\begin{array}{l}\text { Oncocytoma } \\
\text {-TC }\end{array}$ & Males & Solid-cystic & $\begin{array}{c}\text { Variably } \\
\text { sized dilated } \\
\text { tubules, scant } \\
\text { stroma }\end{array}$ & $\begin{array}{l}\text { Cuboidal cells } \\
\text { with intensely } \\
\text { eosinophilic } \\
\text { cytoplasm }\end{array}$ & $\begin{array}{l}\text { Uniform, } \\
\text { round; } \\
\text { nucleoli } \\
\text { variably } \\
\text { present }\end{array}$ & Neg & $\begin{array}{l}\text { Focal } \\
\text { pos }\end{array}$ & Neg & Pos & Neg & Neg \\
\hline MEST & Females & $\begin{array}{l}\text { Usually solid, } \\
\text { rarely cystic }\end{array}$ & $\begin{array}{l}\text { Complex cysts } \\
\text { and tubules, } \\
\text { ovarian-type } \\
\text { stroma }\end{array}$ & $\begin{array}{l}\text { Flat, cuboidal, } \\
\text { or columnar } \\
\text { cells }\end{array}$ & $\begin{array}{l}\text { Low } \\
\text { nuclear } \\
\text { grade }\end{array}$ & Pos & Neg & Variable & Pos & Pos & Pos \\
\hline
\end{tabular}

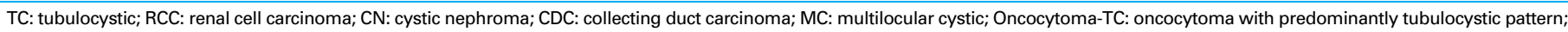
MEST: mixed epithelial stromal tumour; Pos: positive; Neg: negative; SMA: smooth muscle actin; ER: estrogen receptor; PR: progesterone receptor. 
ing ducts. ${ }^{2,9}$ The presence of features of both proximal and distal nephron led Brennan and colleagues to hypothesize an origin from renal tubule stem cells. ${ }^{10}$ As gene expression profiling and detection of molecular alterations (gains in chromosomes 7 and 17, loss of chromosome $\mathrm{Y}$ ) are similar to papillary RCC (PRCC), a relationship between TC-RCC and PRCC has been proposed. ${ }^{3,11}$ Documentation of concomitant TC-RCC and PRCC in same kidney and of foci of PRCC within TC-RCC has supported this proposal.

Radical nephrectomy is the generally recommended treatment for TC-RCC. However, partial nephrectomy may be performed for small superficially located tumours. Not much is known about the use of molecular targeted therapy, with some documented response to sunitinib. ${ }^{12}$ The biological behaviour of these tumours is not well-established. Most tumors have shown indolent behaviour. ${ }^{1}$ However, local recurrences, as well as metastases to lymph nodes, liver, bone and brain have been described..$^{2-7,13}$ One cannot at present be certain of the outcome, especially in unusual cases where there is focal clear cell, papillary or sarcomatoid change.

\section{Conclusion}

Cystic neoplasms of the kidney include a number of entities, including newly described ones. Diagnostic clues lie in the in the neoplastic epithelial component as well as in the stroma. An appropriate panel of immunohistochemical markers is required to arrive at the right diagnosis. In newer entities, patients should be followed up and their outcome reported, as the biological behaviour of cystic neoplasms is still uncertain. In view of the slight, but definite, risk of metastases, all patients diagnosed with TC-RCC should be strictly followed up.

Competing interests: The authors all declare no competing financial or personal interests.

\section{References}

1. Srigley JR, Delahunt B, Eble JN, et al. ISUP renal tumor panel: The international society of urological pathology (ISUP) Vancouver classification of renal neoplasia. Am I Surg Pathol 2013;37:1469-89. http://dx.doi.org/10.1097/PAS.0b013e318299f2dl

2. Amin MB, Maclennan GT, Gupta R, et al. Tubulocystic carcinoma of the kidney: Clinicopathological analysis of 31 cases of a distinctive rare subtype of renal cell carcinoma. Am J Surg Pathol 2009;33:384-92. http://dx.doi.org/10.1097/PAS.0b013e3181872d3f

3. Zhou M, Yang XJ, Lopez II, et al. Renal tubulocystic carcinoma is closely related to papillary renal cell carcinoma: Implications for pathologic classification. Am I Surg Pathol 2009;33:1840-9. hittp://dx.doi. org/10.1097/PAS.0b013e3181be22dl

4. Srigley JR, Delahunt B. Uncommon and recently described renal carcinomas. Mod Pathol 2009;22:S2-S23. http://dx.doi.org/10.1038/modpathol.2009.70

5. Amin MB, Krotty TB, Tickoo SK, et al. Renal oncocytoma: A reappraisal of morphologic features with clinicopathologic findings in 80 cases. Am J Surg Pathol 1997;21:1-12. http://dx.doi. org/10.1097/00000478-199701000-00001

6. Al Hussain TO, Cheng L, Zhang S, et al. Tubulocystic carcinoma of the kidney with poorly differentiated foci: A series of 3 cases with fluorescence in situ hybridization analysis. Hum Pathol 2013;44:1406-11. http://dx.doi.org/10.1016/i.humpath.2012.11.015

7. Sangle NA, Mao R, Shetty $S$, et al. Novel molecular aberrations and pathologic findings in a tubulocystic variant of renal cell carcinoma. Indian J Pathol Microbiol 2013;56:428-33. http://dx.doi. org/10.4103/0377-4929.125361

8. Smith S, Trpkov K, Mehra R, et al. Is tubulocystic carcinoma with dedifferentiation a form of hlrce/ fumarate hydratase-deficient rcc? Modern Pathology 2015;28(S2):260A

9. Alexiev BA, Drachenberg CB. Tubulocystic carcinoma of the kidney: A histologic, immunohistochemical, and ultrastructural study. Virchows Arch 2013;462:575-81. http://dx.doi.org/10.1007/s00428-0131398-0

10. Brennan C, Srigley JR, Whelan C, et al. Type 2 and clear cell papillary renal cell carcinoma, and tubulocystic carcinoma: A unifying concept. Anticancer Res 2010;30:641-4.

11. Chen N, Nie L, Gong J, et al. Gains of chromosomes 7 and 17 in tubulocystic carcinoma of kidney: Two cases with fluorescence in situ hybridisation analysis. J Clin Pathol 2014;67:1006-9. http://dx.doi. org/10.1136/idinpath-2014-202363

12. Mego M, Sycova-Mila Z, Rejekova K, et al. Sunitinib in the treatment of tubulocystic carcinoma of the kidney. A case report. Ann Oncol 2008;19:1655-6.

13. Iakovleva $G$, Iakovlev $V$, Ordon $M$, et al. Tubulocystic carcinoma of kidney: A challenging diagnostic entity mimicking multicystic kidney and presenting with bone metastasis. Histopathology 2015;66:892-4. http://dx.doi.org/10.1111/his.12502

Correspondence: Dr. Mehar Chand Sharma, Department of Pathology, All India Institute of Medical Sciences, New Delhi, India; sharmamehar@yahoo.co.in

This paper has been peer-reviewed. 